\title{
BRAND CAIRNS: AN INSIDER (RESIDENT) STAKEHOLDER PERSPECTIVE
}

\author{
BILL MERRILEES, DALE MILLER, CARMEL HERINGTON, and CHRISTINE SMITH
}

Department of Marketing, Griffith Business School, Griffith University, Queensland 9726, Australia

\begin{abstract}
Usually destination branding is looked at from the visitor's perspective. However, previous literature does not adequately address the perceptions that residents have of their own place of residence. The residents are a major stakeholder in tourism and their perspective has been overlooked, other than their views about tourists. To analyze this perspective, a structural model is developed to explain the formation of residents' attitude to their city brand (Brand Cairns) and further the path to explaining intentions of residents to act as "occasional tourists" in their own city. The statistical tests demonstrate the validity of the structural model.
\end{abstract}

Key words: City branding; Residents; Recreational demand; Community attributes; Occasional tourism

\section{Introduction}

The focus of this study is in understanding city branding from the perspective of the resident. The active role of residents in image studies is the notion that residents of destinations have images of their own place of residence that can be investigated in their own right (Sternquist Witter, 1985). Previous research has primarily focused on the passive role of residents in tourism; that is, what residents think of tourists and tourism and whether or not they are supportive (Cavus \& Tanrisevdi, 2003; Ryan \& Montgomery, 1994; Smith \& Krannich, 1998).

Residents' views of tourism have always been mixed, both positive and negative. The tension that can exist between residents and tourists reflects the notion that they are not mutually exclu- sive entities. During their stay in the destination, tourists are both tourist and (temporary) resident. For their part, residents are both resident and (occasional) tourist within their own environment. By occasional tourist we include the residential use of recreational and tourist facilities, including restaurants and theme parks and even playing the "surrogate tourist" role of spending a weekend at a local hotel/motel and being in the tourist mindset. This is not a new expression. For example, in a UK study of residents' perceptions of tourism, one resident commented: "We are all tourists from time to time" (Ryan \& Montgomery, 1994, p. 364). Also, in the Gold Coast, Australia, local demand for theme parks represents about a third of the total demand. Thus, it is important for tourism management to understand how residents form attitudes about their city (our city branding model) 
and what influences residents' demand for recreational and tourism facilities and acting like a tourist for a day.

Our aim is to understand what the important community attributes are that make a city livable and hence attractive to use the local tourist and recreational facilities. Although not a direct focus of the current study, a corollary of the study is the notion that city branding is a precursor to destination branding. If a city is not attractive to the locals then it is not likely to be very attractive to external visitors/tourists.

A conceptual model of city branding is developed from the literature. The key variable of focus is city brand attitudes of residents. Using city brand attitudes as the core we also study the behavioral consequences of these attitudes (intention to use the tourist and recreational facilities) and the antecedents of brand attitudes (various community attributes).

\section{Literature Review}

Previous research on residents' attitudes to tourism is extensive. We can divide the research into various categories. First, what are residents' overall attitudes to tourism? Some studies have emphasized the negative aspects of tourism on the residents (Pizam, 1978). However, most studies find that there is generally a positive attitude to tourists (Getz, 1994; Rothman, 1978).

Second, how does this attitude to tourism change over time? The negative balance is more likely to worsen over time as tourism develops (maybe overdevelops), changing the residents' attitudes from welcoming to resentment (Allen, Long, Perdue, \& Kieselbach 1988; Doxey, 1975; Smith \& Krannich, 1998). Getz (1994) compared the attitudes of residents of the Spey Valley Scotland to tourism in 1978 and 1992. The attitudes were fairly stable, but with a slight increase in negativity. Getz attributes this greater negativity partly to the industry's poor performance in the years preceding the 1992 survey, partly to a feeling that the local people were not benefiting as much as they should, and partly to a stronger conservation ethic.

Third, residents are not homogeneous in their attitudes to tourism. An increasing number of studies have used segmentation analysis to reflect heterogeneity of residents' perception of tourism (Davis, Allen, \& Cosenza, 1988; T. Evans, 1994; Ryan \& Montgomery, 1994). Ryan and Montgomery (1994) use factor and cluster analysis to classify the attitudes of the residents of the town of Bakewell in the Peak National Park within the UK. The key outcome of the study was the emergence of three groups of residents: $22 \%$ were enthusiasts towards tourism, $24 \%$ were somewhat irritated by tourism, and $54 \%$ were "middle of the roaders" without strong views either way. There was a tendency for longer duration residents to be less supportive of tourism (as also shown in the study by Sheldon \& Var, 1984). The Ryan and Montgomery (1994) research further concluded that being employed in the tourism industry did not affect the results statistically, but we would suggest that the subsample was too small to make any inference on this characteristic. Generally studies have found that persons employed in the tourism industry had more positive attitudes to tourism (Brougham \& Butler, 1981; Pizam, 1978; Rothman, 1978).

Fourth, some studies have examined whether it is possible to influence or change resident attitudes about tourism. The study by Laming (1990) recognizes both tourists and residents can threaten natural resources, so both groups need to be targeted in campaigns to change usage patterns in national parks. The above literature review about residents essentially treats them as passive in the tourism process, save that the residents' negative views have the potential to inhibit or restrict the level of tourist activity.

The active role of residents in image studies is the notion that residents of destinations have images of their own place of residence that can be investigated in their own right (Gallarza, Saura, \& Garcia, 2001). One of the first studies in this realm was Sternquist Witter's (1985) study, with a focus on resident businesses, namely retailers in a tourist location, Traverse City in North Michigan. The retailers' attitudes were compared with those of tourists. Retailers tended to have more positive attitudes of the destination, but also structured differently. The implication from Sternquist Witter (1985) was that different perceptions between resi- 
dent retailers and tourists might result in tourists receiving a less than optimal service.

Other studies with a more active role of residents include Lankford and Howard (1994), who argue that support for tourism is more likely if residents are involved somehow in the planning or evaluation process. Moreover, Ritchie (1988, 1991, 1993) advocates resident-responsive tourism, with the active participation of residents in setting the tourism agenda and determining priorities for tourism development (see also Murdoch, 1993; Murphy, 1985; Robertson \& Crofts, 1992; Snaith \& Haley, 1999). Resident opinions can also guide tourism developments in the form of a type of resident and environmental impact analysis ( $\mathrm{McNi}$ col, 2004).

Perhaps the most relevant resident study for our approach is that of Schroeder (1996). Randomly selected residents of North Dakota were surveyed in terms of their assessment of 20 tourism destination attributes. Key factors included sightseeing, activities, urban (shopping and restaurants), and hospitality (clean environment, friendly local people, moderately priced accommodation). Residents with a more positive overall image were more likely to recommend North Dakota as a place to visit and to support state tourism funding support. Residents with less positive overall image reported more trips and vacations outside the state.

The current article makes the active role of the resident its focus. We argue that there is a need to develop a comprehensive approach to understanding the attitudes of residents in a city to their own city brand. To what extent do residents have a positive attitude to their city brand? What are the main brand associations connected to such a city brand, giving us insight to the components of the brand? City marketing authorities can have a tourist hat, as well as considering other stakeholders such as prospective businesses that wish to invest in a city. In Australia, the city marketing authorities are usually part of local government, while a separate tourism authority is more focused on tourism. The city marketing literature is growing and much of it overlaps with the tourist destination literature. In a study of 12 English cities, Hankinson (2001) shows the diversity of approaches in how city organizations market and brand themselves. In a further study of 25 communities, Han- kinson (2004) found that a community's history, heritage, and culture were important in brand projections. The need for cities to take a strategic approach to their marketing and branding is argued by Buhalis (2000) and reinforced in Uysal, Chen, and Williams (2000). The study by Bramwell and Rawding (1994) indicates the common issues of marketing industrial cities in the five British cities examined, while Evans (2003) explores cultural cities in his European study. The quality of life literature suggests a similar list of community attribute variables in terms of the potential determinants of community satisfaction (Allen, 1990; Parmenter, 1994).

\section{A Proposed Model of City Branding Attitude Formation}

The literature helps inform our development of a relevant conceptual model. Rather than focus on brand attributes per se as components of brand image, we aimed to develop a structural model in which brand attitudes held by residents about their city were determined by various community attributes (brand attributes). Thus, city brand attitudes, as a summative measure, represent the core or central element in our structural model. The threeequation structural model that we propose is as follows:

\section{OTI $=f$ (Brand; Shopping $)$}

2. Brand $=f($ Social $)$

3. Social $=f($ Nature; Vibrancy; Recreation $)$

where $O T I$ is occasional tourism intentions; Brand is the attitude that residents have of their city brand; Social represents social capital and relates to the health of social or interpersonal relations in the community; Nature refers to the natural landscape; Vibrancy refers to business vibrancy in the community including growth of jobs; Recreation refers to recreation facilities.

The first link in the model is the relationship between brand attitudes and behavioral intentions. In different contexts, the link between overall brand attitudes and behavioral intentions has been demonstrated in Delgado-Ballester and MunueraAleman (2001), Low and Lamb (2000), Merrilees and Fry (2002), Sandvik and Duhan (1996), Selnes (1993), and Taylor and Hunter (2003). 
The social, nature, and vibrancy variables can be considered to be community attribute variables or brand associations that help identify communities. Keller (2003) and Kapferer (1997) have conceptualized the relationship between brand attributes or brand associations on one hand, and the overall brand attitude on the other. Overall brand attitudes are a summative measure of the attitudes towards an entity, place, or product, while brand attitudes or associations are perceptions about specific features or attributes that make a connection to the overall attitude. Empirical studies of the overall brand attitude and brand attributes include Delgado-Ballester and Munuera-Aleman (2001), Low and Lamb (2000), Merrilees and Fry (2002), Sandvik and Duhan (1996), Selnes (1993), and Taylor and Hunter (2003). Notwithstanding this growing literature, previous empirical investigation of the brand attribute and brand attitude relationship has not been applied to the city branding context. The items for the occasional tourist intentions and city brand attitudes were developed from Delgado-Ballester and Munuera-Aleman (2001), Low and Lamb (2000), Merrilees and Fry (2002), Sandvik and Duhan (1996), Selnes (1993), and Taylor and Hunter (2003) and adapted to the occasional tourist context.

If city brand attitude is considered the central construct in our structural model, then community attributes are the antecedents. Previous studies such as Schroeder (1996) suggest variables such as nature, recreational activities, urban (shopping and restaurants), and hospitality (friendliness, accommodation) as relevant community variables. Other studies have indicated culture and history as further possible relevant community variables. Social capital is a relatively new construct, building on the seminal work of Putnam (1993, 1995). It is synonymous with social cohesion and emphasizes interpersonal relationships, social relations, friends and family, interactions and ties, and cultural tolerance (see also Berger-Schmitt, 2002; Robinson, 2002). Previous studies of destinations have either ignored social capital or only covered fragments of it, such as lack of crime or say friendliness. A more holistic, composite approach is proposed in the current study. The items for the social capital construct were developed from Berger-Schmitt (2002), Putnam (1993, 1995),
Robinson (2002), and Watters (2004). The items for the vibrant community construct were developed from Florida (2003). The items for the shopping and restaurant construct were developed from Schroeder (1996) and Yuksel (2004). The items for the recreation construct were developed from Allen (1990) and Schroeder (1996).

\section{Methodology}

Given that we are developing a city branding model from the resident perspective, it was decided to use a reasonably large city by Australian standards. Cairns, Queensland was chosen because the city is a major tropical tourist destination in Australia, with impressive natural assets, including easy access to rainforests and the Great Barrier Reef. The population of Cairns is approximately 126,000 (Australian Bureau of Statistics, 2001).

Sampling was stratified with random selection within each strata. The strata groups were eight suburbs selected to give a good cross section of suburbs by socioeconomic groups. The surveys were then randomly distributed to households within each selected suburb by a direct to household, letterbox delivery firm. The response rate of $12 \%$ provided 360 usable surveys for analysis. A comparison of early and late responses was undertaken to discount nonresponse bias (Armstrong \& Overton, 1979). Using independent sample $t$-tests of significance of mean differences for each item across the early and later respondent subsamples provided evidence of no items being statistically significantly different based on the response time.

The self-administered survey instrument was designed in a way to make it user friendly. All variables were measured with multi-item scales and measurement items were measured by 7-point Likert scales ( $1=$ strongly disagree, $7=$ strongly agree), requiring a circle to complete the answer. The demographic variable scales differed depending on the element (e.g., with seven options for age and two for gender).

Analysis was conducted in two stages following Anderson and Gerbing's (1988) recommendations. The first stage consisted of purifying the initial measures. Confirmatory factor analysis was used to assess the unidimensionality and validity of each of the construct measures. For the second 
stage, structural equation modeling using AMOS (version 4) was used to estimate the model.

The model was assessed using a partially disaggregated approach. Partial disaggregation involves the creation of two or more composite variables for each construct (Bentler \& Wu, 1995; Dabholkar, Thorpe, \& Rentz, 1996). The composites may be created from identified subdimensions of an indicator construct of the overall latent construct (Bagozzi \& Heatherton, 1994) or items may be allocated and aggregated randomly as "it is expected that any combination of a construct's variable indicators should yield the same model fit" (Dabholkar et al., 1996, p. 10). The latter approach was taken for this research. Partial disaggregation provides particular benefits of being able to assess a complex higher order model while reducing the level of random error, more stable estimates from reducing the number of parameters to be estimated, and improving approximation of normality distributions (Bagozzi \& Heatherton, 1994; Dabholkar et al., 1996).

\section{Results}

The results are reported in two sections corresponding to the two phases of measurement and structural model estimation suggested by Gerbing and Anderson (1988). Note that Recreation was found to have no statistically significant influence and has not been included in the final set of results.

\section{Measurement Phase}

The six constructs used in the analysis (occasional tourism usage, city brand attitudes, social capital, nature, shopping, and business vibrancy) were jointly measured using confirmatory factor analysis. All of the confirmatory factor analysis tests were affirmative in support of the relevant construct. The goodness of fit indices were all appropriately high, including $\mathrm{GFI}=0.95$; $\mathrm{AGFI}=$ 0.91; NFI $=0.97$. All exceeded the benchmark of 0.90 (Hair, Anderson, Tatham, \& Black, 1995), so we conclude that the data fit the model. Similarly, there was no evidence of misfit. For example, RMSEA was 0.068 , appropriately less than the benchmark of 0.08 (Hair et al., 1995). Standardized RMR was 0.028 , less than the benchmark of
0.05 (Ullman, 2001). The normed chi-square was 2.66 , less than the benchmark of 3 (Carmines \& McIver, 1981). All of the relevant statistics were favorable relative to the benchmarks and so we concluded that the model and its constructs have overall measurement validity.

Some additional tests were carried out. All of the paths between the latent constructs and the manifest variables were statistically significant, indicating convergent validity. Further, all of the exogenous variable constructs demonstrated discriminant validity evidenced by having correlation coefficients that were significantly different from 1.0. Moreover, all of the constructs were unidimensional, based on factor analysis that indicated only one factor per construct. Finally, all of the constructs were reliable, evidenced by Cronbach alphas greater than 0.70 (Nunnally \& Bernstein, 1994), ranging from 0.72 to 0.87 .

We conclude by saying that the measurement phase of the analysis was positive, with support from all of the tests carried out, affirming validity and reliability.

\section{Structural Equation Modeling Estimation}

Phase two of the Anderson and Gerbing (1988) approach involves structural equation modeling. Table 1 reports the SEM results with the model presented in Figure 1.

First, the data fit the model well, with GFI = 0.95, AFGI $=0.91$, and $\mathrm{NFI}=0.96$, all greater than the benchmark of 0.90 . With RMSEA =

\section{Table 1}

Structural Equation Modeling of Cairn's Residents in Terms of Their City Brand Attitudes and Occasional Tourist Activity

\begin{tabular}{ll}
\hline Path & $\begin{array}{c}\text { Regression } \\
\text { Coefficient } \\
(t \text {-Value })\end{array}$ \\
\hline $\begin{array}{l}\text { Path from brand attitude to occasion tourist } \\
\text { Path from shopping \& restaurant to occasional }\end{array}$ & $0.35(3.97)^{* *}$ \\
$\quad$ tourist & $0.29(3.12)^{* *}$ \\
Path from social capital to brand attitude & $0.92(25.43)^{* *}$ \\
Path from nature to social capital & $0.84(14.07)^{* *}$ \\
Path from business vibrancy to social capital & $0.13(2.57)^{*}$ \\
\hline
\end{tabular}

$\mathrm{GFI}=0.95 ; \mathrm{AGFI}=0.91 ; \mathrm{NFI}=0.96$.

*Significant at the 0.05 level.

**Significant at the 0.01 level. 


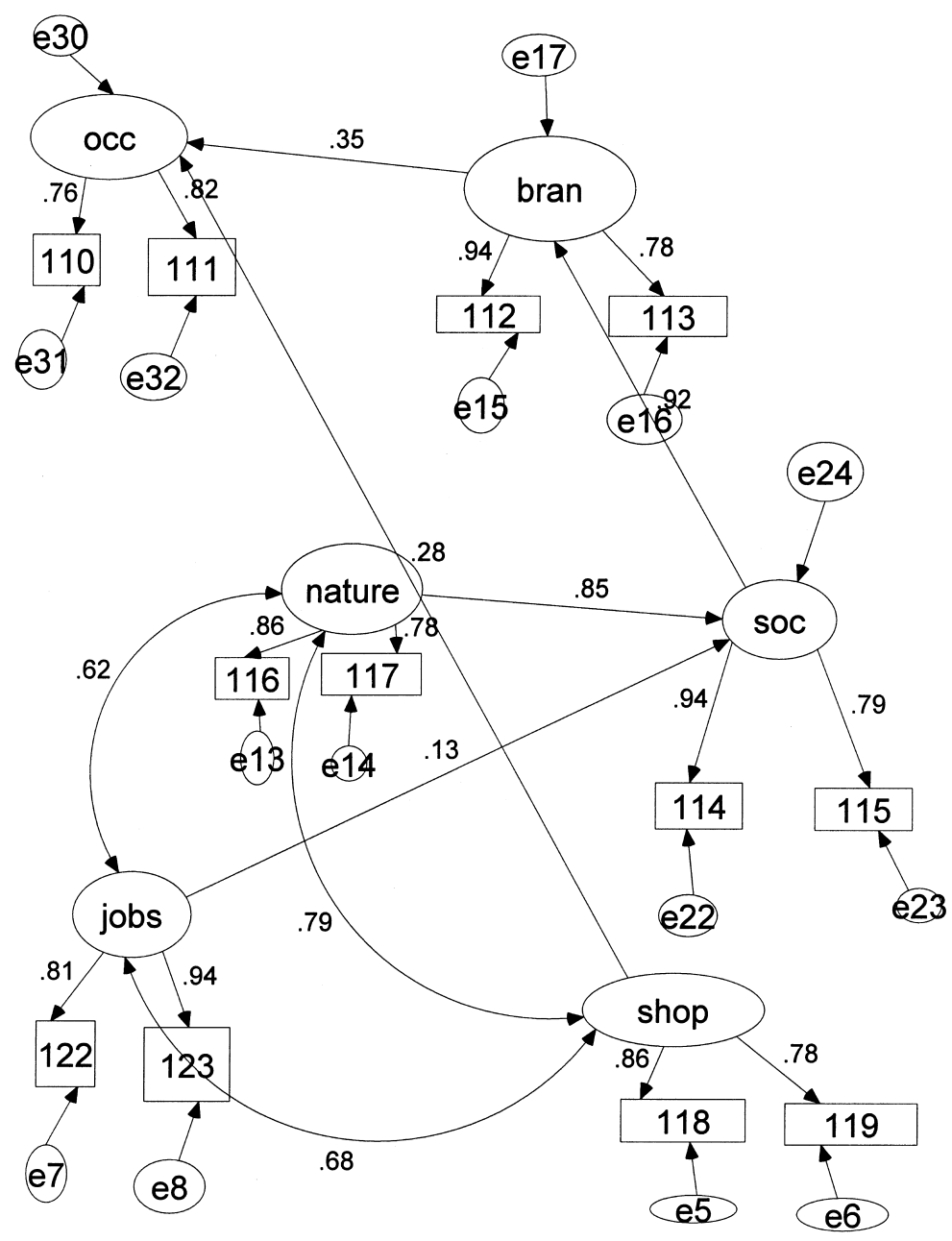

Figure 1. Structural model of city branding.

$0.064, \mathrm{RMR}=0.031$, and normed chi-square of 2.48 , there was no evidence of misfit between the data and the model.

Second, all of the paths in SEM are positive as expected and significant at the $1 \%$ level (if we include one case where it was significant at exactly $0.01)$.

Third, if we focus on the determinants of occasional tourist activity we ascertain that city brand attitudes by residents are the strongest influence on such activity, slightly ahead of perceptions of shopping and restaurant facilities.

Fourth, if we focus on the determinants of city brand attitudes only one influence is significant, namely social capital.
Finally, if we have a closer look at the determinants of social capital, nature is by far the strongest influence, although business vibrancy is also highly significant.

\section{Discussion and Implications for Tourism Research}

The study has estimated a city branding model for a major tourist city, Cairns, in tropical Australia. Both the measurement and the structural model estimation phases were found to be valid and therefore acceptable. Residents' city brand attitudes are used as the central construct of our structural model, representing an innovative ap- 
proach to community research. The consequences of city brand attitudes are in terms of explaining the usage intentions of residents as occasional tourists. The antecedents of city brand attitudes are in the first instance driven by social capital. However, the main influence on social capital and therefore the ultimate source of community satisfaction and occasional tourist usage is nature.

The strong role of nature in a naturally endowed tourist location like Cairns is not a surprise, with world-renowned appreciation of the rainforest and Barrier Reef assets. Notwithstanding, the almost total domination of nature relative to "man-made" community attributes was a slight surprise. The fact that the results so strongly support the role of nature as a driver of tourist usage adds face validity to the results and to the model in general. However, in future studies we would expect the weighting of the critical determinants to vary with different types of tourist destinations.

The social capital community attribute seems to be extremely important for residents as a mediating variable. Previous tourism branding studies have generally not highlighted the critical role of social capital, partly because of oversight (Gallarza et al., 2001). However, an additional problem with previous tourism destination studies is that they have not incorporated a holistic measure of the social capital construct (as defined in this study), but rather piecemeal fragments of the construct, such as free from crime and friendliness, as separate attributes.

\section{Implications for Tourism and Local Government Authorities}

The most immediate use of the results is in terms of understanding local demand for recreation, entertainment, and dining activities. Local demand for such services is stimulated in our sample mainly by city brand attitudes. Nature was seen as the ultimate source of resident motivation, so basing facilities around nature seems the most obvious tourism management approach for a destination like Cairns. However, other aspects like shopping and restaurants and business vibrancy also makes a contribution, so these become complementary approaches for authorities and business ventures to build local demand.
Both local government and tourist authorities have a vested interest in building strong community brands from the residents' perspective. To do this effectively, tourist authorities need to work collaboratively with local government authorities, which is sometimes the case. However, in a study of seven European heritage cities, it was found that tourism management and urban management were generally not well integrated. Bus routing in Salzburg was one of the positive exceptions (Borg, Costa, \& Gotti, 1996). This article highlights a common agenda across the various authorities, one that was not as overt previously. Interauthority collaboration in building community/destination brands might be more effective if the common agenda is made explicit. A stakeholder approach would be an appropriate method to proceed. For example, the Gold Coast (Australia) tourist and local government bodies are recognizing this need.

The city branding framework developed and tested in this study in the context of residents provides tourism authorities with the opportunity to develop tourist destination brands that reflect contemporary society and not some alienating, artificial alternative. This should allow tourist brands to maintain a fresh image and evolve in a way that they remain relevant to the changing needs of visitors and not locked in a time vacuum. As an example, linking of the tourist brand to the residential lifestyle brand is a key part of the newly launched Gold Coast destination tourist brand.

\section{Conclusions}

The focus of the study has been on the active role of residents in a destination (i.e., in terms of the brand images of their own place of residence). A sample of 360 residents from Cairns in Queensland, Australia was used to test our model. All constructs were tested for validity, using confirmatory factor analysis, and found to be valid. Estimation of the parameters has been derived using structural equation modeling. In contrast to most previous related research, we centered on overall brand attitudes as the core of the model.

Our structural model is confirmed using the usual criteria for SEM, such as fit indices. We are able to explain the intention of residents to use tourist and recreational facilities in their home 
city. City brand attitudes play a major role in such intentions, though this in turn is driven largely by social capital. Ultimately for the city of Cairns, nature becomes the primary source of developing positive attitudes that lead to occasional tourist usage. In a richly naturally endowed tourist destination such as Cairns, with ready access to major assets of rainforests and the Great Barrier Reef, it is reassuring that nature is such an important influence. Such a finding adds to the face validity of the structural model.

Social capital has been neglected in most tourism destination studies. When it has been included it has been on a fragmentary basis, using separate constructs, such as friendliness or security against crime. Our recommendation is that tourism destination studies should be revisited, using the social capital construct developed and tested in this article. If this were done, we might see social capital switch from being a low importance psychological influence to a major determinant of tourism destination image.

Our contribution is a better understanding of what makes a city livable and, by inference, visitable. Nature and facilities have important roles to play, but essentially it is people (through the social capital construct), not structures, that make the biggest difference.

\section{References}

Allen, L. (1990). Benefits of leisure attributes to community satisfaction. Journal of Leisure Research, 22(2), 183-196.

Allen, L., Long, P., Perdue, R. \& Kieselbach, S. (1988). The impact of tourism development on citizens' perceptions of community life. Journal of Travel Research, $27,16-21$.

Anderson, J. C., \& Gerbing, D. W. (1988). Structural equation modeling in practice: A review and recommended two-step approach. Psychological Bulletin, 103(3), 411-423.

Armstrong, S., \& Overton, T. (1979). Estimating nonresponse bias in mail surveys. Journal of Marketing Research, 14(3), 396-402.

Australian Bureau of Statistics. (2001). Census of population and housing. Retrieved June 24, 2005, from http:// www.abs.gov.au/Ausstats/abs@census.nsf/Lookup2001 Census/78FEA6342977A87BCA256BBF00013B0D

Bagozzi, R. P., \& Heatherton, T. F. (1994). A general approach to representing multifaceted personality constructs: Application to state self-esteem. Structural Equation Modeling, 1(1), 35-67.
Bentler, P. M., \& Wu, E. J. C. (1995). EQS for Windows user's guide. Encino, CA: Multivariate Software Inc.

Berger-Schmitt, R. (2002). Considering social cohesion in quality of life assessments: Concepts and measurement. Social Indicators Research, 58, 403-428.

Borg, J., Costa, P., \& Gotti, G. (1996). Tourism in European heritage cities. Annals of Tourism Research, 23(2), 306-321.

Bramwell, B., \& Rawding, L. (1994). Tourism marketing organizations in industrial cities. Tourism Management, 15(6), 425-434.

Brougham, J., \& Butler, R. (1981). A segmentation analysis of resident attitudes to the social impact of tourism. $A n$ nals of Tourism Research, 8(4), 569-589.

Buhalis, D. (2000). Marketing the competitive destination of the future. Tourism Management, 21, 97-116.

Carmines, E. G., \& McIver, J. P. (1981). Analyzing models with unobserved variables: Analysis of covariance structures. In G. W. Bohrnstedt \& E. F. Borgatta (Eds.), Social measurement: Current issues. Beverley Hills, CA: Sage.

Cavus, S., \& Tanrisevdi, A. (2003). Residents' attitudes towards tourism development: A case study in Kusadasi, Turkey. Tourism Analysis, 7, 259-269.

Dabholkar, P. A., Thorpe, D. I., \& Rentz, J. O. (1996). A measure of service quality for retail stores: Scale development and validation. Journal of the Academy of Marketing Science, 24(1), 3-16.

Davis, D., Allen, J., \& Cosenza, R. (1988). Segmenting local residents by their attitudes, interests and opinions towards tourism. Journal of Travel Research, 27(2), $2-8$.

Delgado-Ballester, E., \& Munuera-Aleman, J. (2001). Brand trust in the context of consumer loyalty. European Journal of Marketing, 35(11\&12), 1238-1258.

Doxey, G. (1975). A causation theory of visitor-resident irritants. Sixth Conference Proceedings of the Travel and Tourism Research Association (pp. 195-198), San Diego.

Evans, G. (2003). Hard branding the cultural city-from Prado to Prada. International Journal of Urban and Regional Research, 27(2), 417-440.

Evans, T. (1994). Residents' perception of tourism in selected New Zealand communities: A segmentation study. Unpublished M.Com. thesis, University of Otago, Dunedin, New Zealand.

Florida, R. (2003). The rise of the creative class. Melbourne: Pluto Press.

Gallarza, M., Saura, I., \& Garcia, H. (2001). Destination image: Towards a conceptual framework. Annals of Tourism Research, 29(1), 56-78.

Getz, D. (1994). Residents' attitudes towards tourism: A longitudinal study in Spey Valley, Scotland. Tourism Management, 15(4), 247-258.

Hair, Jr., J. F., Anderson, R. E., Tatham, R. L., \& Black, W. C. (1995). Multivariate data analysis (4th ed.). Englewood Cliffs, NJ: Prentice Hall.

Hankinson, G. (2001). Location branding: A study of the 
branding practices of 12 English cities. Journal of Brand Management, 9(2), 127-142.

Hankinson, G. (2004). The brand images of tourism destinations: A study of the saliency of organic images. Journal of Product \& Brand Management, 13(1), 6-14.

Kapferer, J. (1997). Strategic brand management. London: Kogan Page.

Keller, K. (2003). Strategic brand management. Upper Saddle River, NJ: Prentice Hall.

Laming, R. (1990). The national parks: Loved to death. UK CEED Bulletin, 27, 15-17.

Lankford, S., \& Howard, D. (1994). Developing a tourism impact scale. Annals of Tourism Research, 21(1), 121139.

Low, G., \& Lamb, C. (2000). The measurement and dimensionality of brand associations. Journal of Product and Brand Management, 9(6), 350-368.

$\mathrm{McNicol,} \mathrm{B.} \mathrm{(2004).} \mathrm{Group} \mathrm{destination} \mathrm{images} \mathrm{of} \mathrm{proposed}$ tourism resort developments: Identifying resident versus developer contrast. Tourism Analysis, 9, 41-53.

Merrilees, B., \& Fry, M. (2002). Corporate branding: A framework for e-retailers. Corporate Reputation Review, 5(2\&3), 213-225.

Murdoch, J. (1993). Review of the economic impact of holiday villages: A report for the Rural Development Commission. Journal of Sustainable Tourism, 1(2), 145.

Murphey, P. (1985). Tourism: A community approach. New York: Methuen.

Nunnally, J. C., \& Bernstein, I. H. (1994). Psychometric theory (3rd ed.). New York: McGraw-Hill.

Parmenter, T. (1994). Quality of life as a concept and measurable entity. Social Indicators Research, 33, 9-46.

Pizam, A. (1978). Tourism's impacts: The social costs to the destination as perceived by its residents. Journal of Travel Research, 16(4), 8-12.

Putnam, R. (1993). The prosperous community: social capital and public life. American Prospect, 13, 35-42.

Putnam, R. (1995). Bowling alone: America's declining social capital. Journal of Democracy, 6, 65-78.

Ritchie, B. (1988). Consensus policy formulation in tourism: Measuring resident views via survey research. Tourism Management, 9, 199-212.

Ritchie, B. (1991). Global tourism policy issues: an agenda for the 1990s. World Tourism Review, 1, 149-158.

Ritchie, B. (1993). Crafting a destination vision-putting the concept of resident-responsive tourism into practice. Tourism Management, 14(3), 379-389.

Robertson, C., \& Crofts, J. (1992). Information effects on residents' perception of tourism development. Visions of Leisure and Business, 11(1), 32-39.
Robinson, D. (Ed.). (2002). Building social capital. Wellington: Institute of Policy Studies.

Rothman, R. (1978). Residents and transients: Community reaction to seasonal visitors. Journal of Travel Research, 16(1), 8-13.

Ryan, C. \& Montgomery, D. (1994). The attitudes of Bakewell residents to tourism and issues in community responsive tourism. Tourism Management, 15(5), 358369.

Sanvik, K., \& Duhan, D. (1996). The effects of performance quality, customer satisfaction and brand reputation on customer loyalty. In J. Beracs, A. Bauer, \& J. Simons (Eds.), EMAC Conference Proceedings (pp. 983-999), Budapest.

Schroeder, T. (1996). The relationship of residents' image of their state as a tourist destination and their support for tourism. Journal of Travel Research, 34, 71-73.

Selnes, F. (1993). An examination of the effect of product performance on brand reputation, satisfaction and loyalty. European Journal of Marketing, 27(9), 19-35.

Sheldon, P., \& Var, T. (1984). Resident attitudes to tourism in North Wales. Tourism Management, 5(1), 40-47.

Smith, M., \& Krannich, R. (1998). Tourism dependence and resident attitudes. Annals of Tourism Research, 25(4), 783-802.

Snaith, T., \& Haley, A. (1999). Residents' opinions of tourism development in the historic city of York, England. Tourism Management, 20, 595-603.

Sternquist Witter, B. (1985). Attitudes about resort area: A comparison of tourists and local retailers. Journal of Travel Research, 24(1), 14-19.

Taylor, S., \& Hunter, G. (2003). An exploratory investigation into the antecedents of satisfaction, brand attitude and loyalty within the (B2B) eCRM industry. Journal of Consumer Satisfaction and Complaining Behavior, $16,19-35$.

Ullman, J. B. (2001). Structural equation modeling. In B. G. Tabachnick \& L. S. Fidell (Eds.), Using multivariate statistics (4th ed., pp. 653-771). Boston: Allyn and Bacon.

Uysal, M., Chen, J., \& Williams, D. (2000). Increasing state market share through a regional positioning. Tourism Management, 21, 89-96.

Watters, E. (2004). Urban tribes: Are friends the new family? London: Bloomsbury.

Yuksel, A. (2004). Shopping experience evaluation: A case of domestic and international visitors. Tourism Management, 25, 751-759. 